\title{
Variability of the Russian populations of Puccinia triticina under the influence of the host plant
}

\section{Elena Gultyaeva, Mark Levitin, and Ekaterina Shaydayuk}

Laboratory of Mycology and Phytopathology, All Russian Institute of Plant Protection, Shosse Podbel'skogo, 3, Saint Petersburg, 190608, Russian Federation

Address correspondence and requests for materials to Elena Gultyaeva, eigultyaeva@gmail.com

\begin{abstract}
The article analyzes our own data and data from the literature on the study of plant-pathogen interactions in the pathosystem of Puccinia triticina and host plants of the genera Triticum and Aegilops with different ploidy and genomes. We characterize the long-term variability of the Russian populations of the pathogen, caused by the cultivation of genetically protected cultivars of common wheat (T. aestivum). Differences of the pathogen's virulence on hexaploid species T. aestivum and tetraploid wheat (T. durum) are shown. Data on the pathogen's virulence on other hexaploid, tetraploid, and diploid relative species Triticum sp. and Aegilops sp. are presented. Adaptation and specificity to the host plant were shown as the key driving factors in the evolution and divergence of clonally propagating phytopathogens, which include leaf rust.
\end{abstract}

Keywords: leaf rust, wheat, Triticum sp., Aegilops sp., Lr-genes, resistance, planthost interaction, pathogen

\section{Introduction}

Leaf rust, caused by Puccinia triticina Erikss., is the most common rust disease of hexaploid common wheat and other Triticum, Aegilops, Elymus and Agropyron species (Fig. 1a). The fungus is heteroecious and therefore requires a telial/uredinial host and an alternative (pycnial/aecial) host (Thalictrum speciosissimum or Isopyrum fumaroides) to complete the full life cycle (Bolton et al., 2008). In the wild, the sexual phase of the P. triticina life cycle is rarely observed, even when wheat grows close to the intermediate host plant (Berlyand-Kozhevnikov et al., 1978). Due to the fact that the wheat leaf rust pathogen has practically lost the sexual stage in its life cycle, its population has a clonal structure, and virulence is its main characteristic. The urediniospores (Fig. 1b) have a dikaryotic nuclear condition and are capable of cycling continuously on the cereal hosts.

The variability of P. triticina populations is mainly due to close interaction with the host plant (mutations, natural selection) and, to a lesser extent, other evolutionary factors (isolation, population waves). The interaction of the populations of the parasite and the host plant leads to their conjugate evolution. The pathogen's adaptation to survival is determined by its virulence and aggressiveness to wheat plants. Wheat plants with highly or partially effective genes for race-specific resistance undergo the primary selection of pathogen clones according to the corresponding signs of virulence, and the non-virulent part of the population is eliminated. Initially, a virulence mutation occurs in one pathogen genotype; in subsequent years, it can be found in other genotypes. Multiple sizes of the P. triticina population suggests multiple repetitions of virulence mutations. Mutations and subsequent selection of specific virulence by host genotypes that have corresponding resistance 

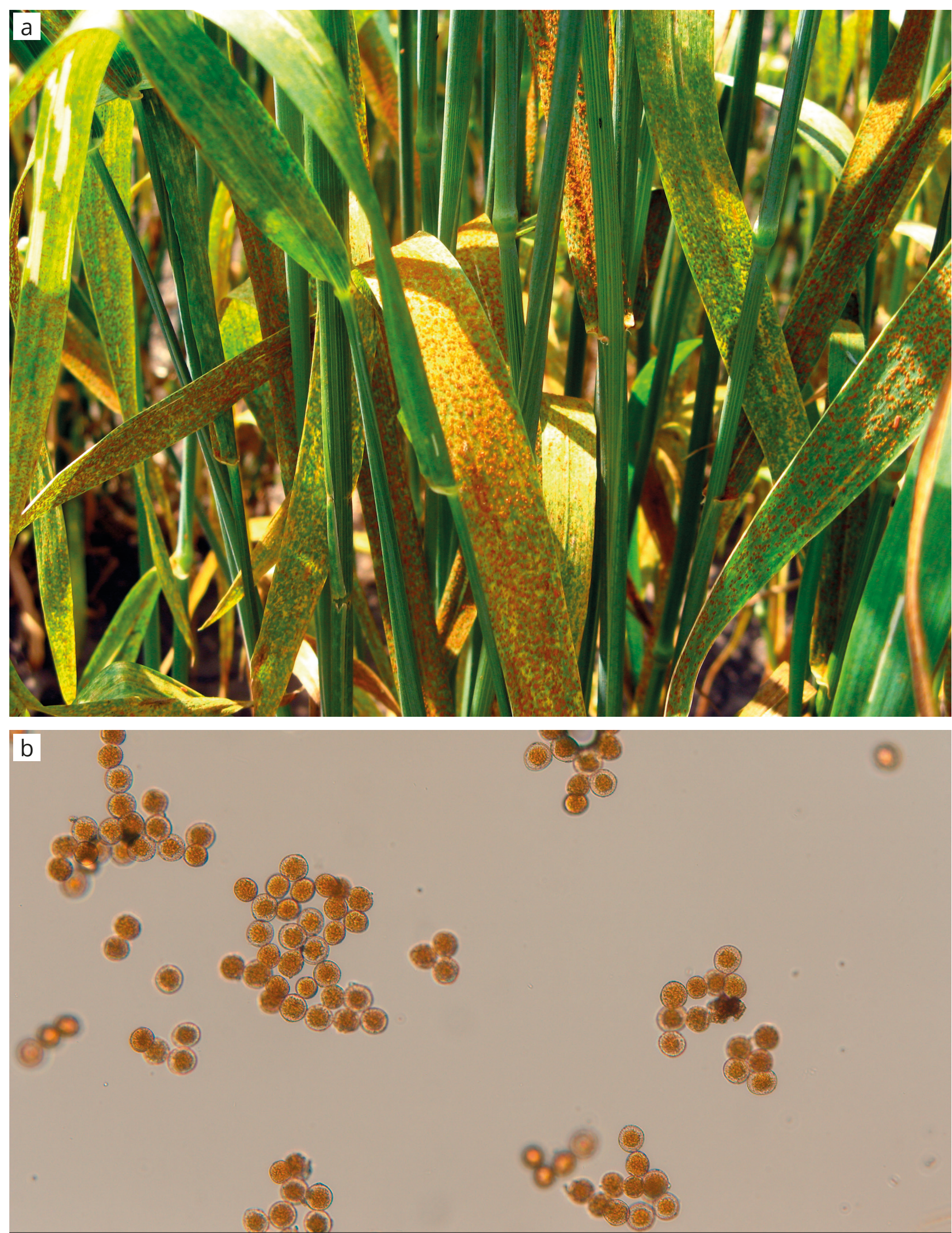

Fig. 1. Symptoms of wheat infection by leaf rust fungus Puccinia triticina (a) and urediniospores of fungus (b) 
genes provide the diversity and dynamics of populations in terms of virulence phenotypes (Mikhailova, 2006).

Long-term studies of P.triticina populations in Russia and abroad confirm the primary role of natural selection in the formation and variability of pathogen populations. Studies of the structure of populations of the leaf rust pathogen in Russia have been carried out since the 1930s (Barmenkov, 1937) at the All-Russian Research Institute of Plant Protection and other scientific institutions. In the same period, work began on the breeding of wheat for resistance to this pathogen (Vavilov, 1938). Undoubtedly, an increase in the genetic diversity of the host plant predetermined the variability of the pathogen. In this regard, analysis of the evolution of the pathosystem Puccinia triticina x Triticum sp. over such a long period of time seemed relevant.

\section{The Puccinia triticina/Triticum aestivum interaction}

In 1930-1940, the relative stability of the Russian populations of P.triticina was noted. The racial composition of the pathogen during this period was highly similar to the Western European and North American populations (Barmenkov, 1937). The reason for this was the widespread cultivation of highly susceptible, genetically unprotected wheat cultivars.

The first significant changes in the racial composition of populations of the leaf rust pathogen on hexaploid common wheat (Triticum aestivum L. $2 \mathrm{n}=42$, BBAADD genome) in the former USSR territory occurred in the 1950s. During this period, an increase was noted in the occurrence of race 77 and its biotypes, as well as races 20,21, 52, and others that were previously absent (Shopina, 1969; Sorokina and Solomatin, 1975). In 1965-1968, everywhere, both in Russia and around the world, the quantity of race 122 began to increase. According to V.V.Shopina (1969), this was due to the cultivation of genetically similar cultivars in different countries and the use of similar resistance donors in plant breeding.

In the early 1970s another significant shift in the composition of P.triticina populations took place, resulting from the infection of the widely grown cvs. Aurora, Kavkaz, Bezostaya 1, Skorospelka 35, etc., which were previously characterized as leaf rust resistant. As a result, the previously dominant races and biotypes of the pathogen had almost completely disappeared in the North Caucasus and neighboring regions by 1973; they were replaced by races virulent to cultivars and lines with the Lr26 gene (Sanin, 1975; Voronkova, 1975; Lesovoi, Suvorova, 1985). The loss of resistance to rust in cvs. Aurora and Kavkaz is due to a number of circumstances. By the time these cultivars were introduced into production, accessions with the $1 \mathrm{~B}-1 \mathrm{R}$ translocation carrying the Lr26 gene were already being grown in Western
Europe. In the populations of the pathogen of Western European countries, selection of clones virulent to cultivars with this resistance gene took place. The spores of the fungus could have been carried by air currents from Western Europe to the east. Cv. Kavkaz quickly spread over large areas in the USSR and a number of Eastern European countries, which led to the formation of a powerful selective background for the accumulation of virulent clones (Novozhilov et al., 1998).

In 1971-1980, I. G. Odintsova and Yu. A. Khristov (1981) traced the movement paths of spores of the leaf rust pathogen in the former USSR territory. In 1971, the content of clones virulent to cvs. Aurora and Kavkaz was generally low. By 1975, it had increased. Since these cultivars were grown only in the southwestern region of the country, the emergence of virulent clones to them in the north of the European part of the country, in the Volga region, northern Kazakhstan and Western Siberia, was due to the introduction of spores from the cultivation areas of cultivars with this gene. The introduction was also confirmed by the high frequency of virulence to the cultivars used as differentials, Skorospelka 35 and Bezostaya 1, which were not grown in these regions, as well as the similarity of the leaf rust populations of the European part of the country and Western Siberia in terms of the frequency of virulence to the Thatcher series lines. The introduction of spores from Central Asia to Western Siberia and Northern Kazakhstan was observed in 1979. It was assumed that the crops of winter cultivars in the European part are the main overwintering site and the source of spring wheat infection in the rest of the country.

In the 1970s-1980s, alien Lr9, Lr19, Lr23 and Lr24 genes were the most effective in protecting wheat from leaf rust in all regions of Russia and abroad. These genes and a number of alien species (Ag. Intermedium, Ae. Speltoides, T.timotheevii, Ae. Tauschii, etc.) began to be widely used in breeding programs (Tstisin, 1981; Sibikeev et al, 1995; Morgounov et al., 2011). The expansion of the genetic diversity of the host plant stimulated an increase in the diversity of the racial composition of the pathogen population. The pathogen populations especially intensively changed in terms of virulence when new wheat cultivars protected by identical oligogens were introduced into production and grown over large areas.

New clones virulent to Lr23 and Lr19 genes, previously absent in the pathogen population, were identified in the late 1980s in the Volga region. This is explained by the fact that cultivars with $\operatorname{Lr} 23$ and $\operatorname{Lr} 19$ genes began to grow widely in the sown areas of the Volga region (Markelova, 2007; Sibikeev and Krupnov, 2007). The first cv. L503 with the Lr19 gene was included in the State Register in 1993, and in the subsequent period the number of cultivars with this gene began to increase. In 
the mid-1990s, when the sown area for these cultivars exceeded 100 thousand hectares, the protective effect of the $\operatorname{Lr} 19$ gene was overcome. Since 2000, virulence on the Lr19 gene began to be noted in other regions untypical for its cultivation (Zhemchuzhina et al., 2008; Gultyaeva et al., 2009). The occurrence of clones virulent to Lr23 was higher in Ukraine and in the Volga region, where cultivars with this gene were widely grown (Ershovskaya 32, Olimp, Kuibyshevskaya 1, Smuglyan$\mathrm{ka}$, etc.).

In 2000, another change in the structure of the pathogen populations was noted, under the influence of the plant genotype. In 2007, isolates virulent to the previously highly efficient $\operatorname{Lr} 9$ gene were found for the first time in the Asian part of Russia (Meshkova et al., 2008). The first cv. Tertsiya with the $\operatorname{Lr} 9$ gene has been cultivated in Western Siberia since 1995. In the Urals, the spring wheat cvs. Kvinta and Duet with the Lr9 gene were selected at Chelyabinsk Scientific Research Institute of Agriculture, in 1999-2000. Their hybrids were widely used in subsequent crosses, which led to the further spread of the $\operatorname{Lr} 9$ gene in many modern cultivars of Ural and West Siberian breeding. Because of this, the final loss of the effectiveness of this gene in these regions became obvious by the middle of 2010 (Meshkova and Roseeva, 2016). In the modern period, virulence on the $\operatorname{Lr} 9$ gene dominates in the Asian regions of the Russian Federation, where cultivars protected by this gene are widely grown (Gultyaeva et al., 2020). Since mid-2010, similar phenotypes have also been found in European regions (Central Black Earth Region and the Volga region), where winter cultivars with this gene now also grow. Due to the unfortunate probability of migration of populations from the Asian to the European part of Russia, the emergence of isolates virulent to $\operatorname{Lr} 9$ in the European part can be provided by an independent mutation of the pathogen. At the same time, the gene remains effective to date in the North Caucasus and Northwest regions, which are free from cultivars with this gene (Ablova et al., 2016; Gultyaeva, 2018; Volkova et al., 2019).

Since the 2000s, there has been a significant increase in the diversity of the racial composition of P. triticina in the regions of Russia, compared to the previous period (Gultyaeva, 2018; Meshkova et al., 2018, 2019; Volkova et al., 2019). In the same period, there has been an increase in zoning of cultivars of winter and spring wheat resistant to leaf rust (Morgunov et al., 2011; Gultyaeva, 2012, 2018; Tyunin et al., 2017). In the mid-1990s, the total share of cultivars resistant to leaf rust in the State Register did not exceed $4 \%$, while in 2005 it increased up to $15 \%$ and in the subsequent period it continues growing (Gultyaeva, 2018). At the same time, a moderate diversity of new cultivars for resistance genes ( $\mathrm{r}$ genes) is shown. Previously effective Lr19 and Lr9 genes are widespread in spring wheat cultivars. Most cultivars with the Lr19 gene are concentrated in the Volga region (14\% of the total recommended for the region), and those with the $\operatorname{Lr} 9$ gene in the Urals and Western Siberia ( $11 \%$ and $15 \%$, respectively), i.e., in those regions where virulence on these genes is dominant. Despite this fact, there is a certain increase in the number of cultivars with the $\operatorname{Lr} 9$ gene in the State Register after 2010, compared to the previous period. At the same time, there is a decrease among cultivars with the Lr19 gene in the Volga region. In some new zoned wheat cultivars, the $\operatorname{Lr} 9$ and Lr19 genes are combined with the Lr26 gene (Sibikeev et al., 2011; Tyunin et al., 2017), and these cultivars are characterized by a high level of resistance. The annual analysis of P. triticina virulence carried out at the All-Russian Institute of Plant Protection did not find any clones simultaneously virulent to $\operatorname{Lr} 9$ and $\operatorname{Lr} 26$, or Lr19 and Lr26, which explains the effectiveness of this combination of genes. At the same time, such an effect was not observed in combinations of $\operatorname{Lr} 9$ and $\operatorname{Lr} 19$ with low-effective $L r 1, L r 3$, and $L r 10$, which are widely represented in Russian cultivars of winter and spring common wheat (Tyunin et al., 2017; Gultyaeva, 2018). All isolates virulent to $\operatorname{Lr} 9$ or $\operatorname{Lr} 19$ were also virulent to lines with $L r 1, L r 3$ and $L r 10$ genes.

The situation with winter cultivars is somewhat different. Most of the leaf rust resistant winter cultivars are characterized by different levels of horizontal resistance in the field. Many of these cultivars have a combination of ineffective $\operatorname{Lr} 1, \operatorname{Lr} 3, \operatorname{Lr} 10, \operatorname{Lr} 26$ genes and the partial resistance Lr34 gene (Gultyaeva, 2018). Nonspecific (or horizontal) resistance is considered a quantitative trait. It manifests itself in a decrease in the reproductive capacity of the pathogen. Ultimately, this resistance manifests itself in a decrease in the rate of development of epiphytotics. It is assumed to be polygenic, determined by small genes with an additive effect, and persists longer than specific resistance due to the fact that the pathogen population has less chances to accumulate virulence mutations that overcome polygenic resistance. A relevant example is the multi-level system of adaptive use of the gene pool of wheat cultivars, developed by the P. P. Lukianenko National Center for Grain and introduced in the North Caucasus region. It is the key factor not only for an increase in yield and gross grain harvest, but also for the relative stability of the North Caucasian population of P. triticina in virulence, which has been observed in the last decade (Ablova et al., 2016).

\section{The Puccinia triticina/Triticum durum interaction}

Tetraploid Triticum durum Desf wheat $(2 \mathrm{n}=28$, AABB genome) is the second widely cultivated Triticum species parasitized by the fungus $P$. triticina. The genetics of resistance of durum wheat to leaf rust has been studied 
much less well than that of soft wheat; therefore, it is more difficult to trace the influence of the genotype on the variability of populations. Until the 2000 s, the study of the pathogen's virulence on durum wheat was limited worldwide, since T. durum was more resistant to leaf rust than common wheat (Dorofeev et al., 1987). In the early 2000s, durum wheat began to lose its relatively higher species resistance to leaf rust. The epiphytotic development of the disease has been often noted in the regions of T.durum growing in the North and South Americas, Western Europe, and the Mediterranean (Singh et al., 2004). In Russia, in some years, an epiphytotic situation with leaf rust has been also observed.

In 1972-1973, A.P.Dmitriev et al. (1976) studied the virulence of leaf rust isolates from 10 durum wheat samples and revealed the influence of the T.durum genotype on the selection of pathogen races. The studies showed for the first time that P. triticina isolates from durum wheat had a smaller number of virulence alleles compared to isolates from common wheat. Most of the studied isolates were characterized by avirulence on lines with Lr1, Lr2 and Lr17 genes. L. A. Mikhailova and T.G. Metreveli (1986) obtained the same data in their study of samples of populations collected from durum wheat cultivars at the Dagestan Experimental Station of the Federal Research Center N. I. Vavilov All-Russian Institute of Plant Genetic Resources (VIR, 1980-1981) and the Georgian Research Institute of Agriculture (Mtskheta, 1976). The experiments showed high frequencies of pathogen virulence (close to $100 \%$ ) in lines with $\operatorname{Lr} 3 a$, Lr3ka, Lr10, Lr14, Lr16 and Lr18. At the same time, regardless of the degree of damage to durum wheat cultivars used as a source of infection, all their fungal isolates were avirulent to lines with $\operatorname{Lr} 1, \operatorname{Lr} 2 a$ and $\operatorname{Lr} 17$. It was concluded that the ability to select isolates avirulent to Lr1 and $L r 2 a$ in durum wheat is more pronounced than in common wheat (Dmitriev et al., 1976; Mikhailova, 2006).

In 2014, this information was confirmed by E. I. Gultyaeva et al. (2016) in their study of populations of P.triticina on Damsinskaya 90 and Kharkovskaya 4 durum wheat cultivars grown in the Shortandinskaya region of Northern Kazakhstan. These studies, similar to the above (Dmitriev et al., 1976; Mikhailova, 2006), show lower virulence of isolates from durum wheat compared to common wheat.

In 2017-2019, the All-Russian Institute of Plant Protection continued studies on populations of durum wheat (Shaydayuk et al., 2019; Shaydayuk, 2020). Geographically distant populations of P.triticina - North Caucasian (including samples from Dagestan, Krasnodar Krai and Rostov Oblast), Volga (Samara Oblast and Chuvashia), Ural (Chelyabinsk Oblast) and West Siberian (Altai Territory and Omsk Oblast) populations were studied. The North Caucasian populations were collect- ed from winter cultivars, and all others were from spring cultivars. All studied isolates were avirulent to lines with Lr2a, Lr2b, Lr2c, Lr9, Lr15, Lr16, Lr19, Lr24, Lr28, Lr29, Lr41, Lr45, Lr47, Lr51, Lr52, Lr53 genes, and virulent to Lr1, Lr3a, Lr3bg, Lr3ka, Lr11, Lr14a, Lr14b, Lr18, Lr26, Lr30, Lr32, Lr33, Lr34, Lr48, Lr49, Lr64 genes. Regional populations differed significantly in virulence on the TcLr17 and TcLr44 lines. The North Caucasian samples of populations from winter cultivars of durum wheat had significantly lower frequencies of virulence on TcLr17 than the Volga, Ural, and West Siberian samples, and higher virulence on TcLr44. The frequencies of virulence on TcLr20, TcLr23 and TcLr26 spontaneously varied in all studied populations (Shaydayuk, 2020). Russian isolates of P. triticina from durum wheat in 2017-2019 differed in virulence from isolates from other countries, which may be due to differences in the cultivated composition of T.durum genotypes in different countries (Martinez et al., 2005; Ordoñez et al., 2007; Mantovani et al., 2010; Goyeau et al., 2012).

Changes in virulence compared to 1970-1980 are noted in the modern Dagestan population of P.tritici$n a$ of durum wheat. In the mid-1970s, all isolates from T. durum were avirulent to lines with $\operatorname{Lr} 1, \operatorname{Lr} 2 a, \operatorname{Lr} 2$ c, Lr3a and Lr17 (Dmitriev et al., 1976). In the 1980s, the avirulence on TcLr1 and TcLr2a persisted, but the frequency of virulence on TcLr3a, TcLr3ka, TcLr10, TcLr14, TcLr16, TcLr17 and TcLr18 increased (Mikhailova and Metreveli, 1986; Mikhailova, 2006). The analysis carried out in 2017-2019 showed that all Derbent isolates are avirulent to $\operatorname{Lr} 2 a, \operatorname{Lr} 2 b, \operatorname{Lr} 2 c, \operatorname{Lr} 16$ and $\operatorname{Lr} 17$ and virulent to $L r 1$. For common wheat, an increase in virulence on Lr1 in Russian populations has been observed since the beginning of 2010, which is caused by an increase in the cultivated range of cultivars with this gene (Gultyaeva, 2018).

Studies of the populations in 2017-2019 revealed significant differences in virulence and phenotypic composition between isolates from durum and common wheat. Collections of infectious material from the two species of wheat were made at identical points. Isolates from common wheat had a greater number of virulence alleles compared to those from durum wheat. No common phenotypes were found on durum and soft wheat (Shaydayuk et al., 2019; Shaydayuk, 2020). The virulence phenotypes of common wheat differed from those of durum wheat in all study areas, which indicates a difference in the composition of pathogen populations of T. durum and T. aestivum. The results obtained are consistent with those presented in the world and domestic literature on the effect of the durum wheat genome on selecting less virulent isolates than common wheat cultivars (Dmitriev et al., 1976; Berlyand-Kozhevnikov et al., 1978; Mikhailova and Metreveli, 1986; Martinez et al., 
2005; Ordoñez and Kolmer, 2007; Goyeau et al., 2012; Aoun et al., 2020).

\section{The Puccinia triticina/alien cereals species (Triticum sp., Aegilops sp.)}

P. triticina infects both common and durum wheat and other cultivated and wild crops of the genera Triticum, Aegilops, Secale, Hordeum, Elymus, Agropyron and Bromus (Bolton et al., 2008). The coevolution of P. triticina and its host plants - wheat and Aegilops species in the process of wheat domestication - undoubtedly predetermined the genetic divergence of the fungus. It has been shown that Triticum and Aegilops, as well as common wheat cultivars, thoughtfully select pathogen clones (Berlyand-Kozhevnikov et al., 1978; Mikhailova, 2006; Liu et al., 2014; Gultyaeva, 2018). Diploid wheat is generally characterized by high resistance to leaf rust; hexaploid wheat - by strong susceptibility; and tetraploid wheat occupies an intermediate position, being widely variable in resistance between different species (Berlyand-Kozhevnikov et al., 1978).

The centers of origin of the species are believed to have the greatest genetic diversity. Southern Dagestan belongs to the Central Asian genesis center of wheat and its joint evolution with parasites, including the leaf rust pathogen. The Dagestan Experimental Station of the Federal Research Center N. I. Vavilov All-Russian Institute of Plant Genetic Resources, located in South Dagestan (Derbent District), conducts annual studies of a genetically diverse collection of wheat and Aegilops, which in general represents the leaf rust resistant gene pool. Wild cereals grow around the station, including wheatgrass and Aegilops species susceptible to leaf rust. In 20142017, we studied a collection of P. triticina isolates from the diploid (2n=14) Ae. caudata L., Ae. sharonensis Perc., Ae. tauschii (Coss.) Schmalh., T. monococcum L. species; tetraploid $(2 \mathrm{n}=28)$ T.aethiopicum Jakubz., T. turanicum Jakubz., T. dicoccoides (Körn. ex Asch. \& Graebner) Schweinf., T.durum, T. dicoccum (Schrank) Schubl.), T.polonicum L., T.persicum Vav. ex Zhuk, Ae. crassa Boiss; and hexaploid $(2 \mathrm{n}=42)$ Ae. juvenalis (Thell.). Eig., Ae. trivialis (Zhuk.) Migusch. et Chak., T. compactum Host., T. macha Dekapr. et Menabde, T. petropavlovskyi Udacz. et Migusch., T. spelta, T.sphaerococcum Perc., T. vavilovii Jakubz., and T.aestivum species and confirmed its high genotypic diversity in virulence in Triticum sp. and Aegilops sp. (Gultyaeva, 2018). The analysis of virulence revealed differences in virulence between P.triticina isolates from tetraploid and hexaploid host species. Isolates from common wheat were characterized by a high degree of similarity with isolates from other hexaploid species (T.compactum, T.macha, T.petropavlovskyi, T.spelta, T. sphaerococcum, T. vavilovii and Ae. trivialis). Isolates from the tetraploid $P$. triticina species were char- acterized by a smaller number of virulence alleles ( 9.4 of 20) than from the hexaploid (13.2) and diploid Ae. tauschii (14.5) species. Isolates from the diploid T.tauschii and T.monococcum (15 of 20) had a greater number of virulence alleles compared to Ae. sharonensis and Ae. caudata (10) (Gultyaeva, 2018).

The world literature previously presented information on the differences in the virulence of the pathogen isolates from T.durum, T.aestivum, and Ae. speltoides (Ordoñez et al., 2007; Mantovani et al., 2010). The sequencing of the RPB2 intron-containing regions and Puccinia informative SSR loci has proved the independent divergence of the fungus on the diploid host Ae. speltoides (genome B donor for common wheat), on tetraploid Ethiopian forms of durum wheat (T. durum) and on hexaploid common wheat (T. aestivum) (Liu et al., 2014).

Thus, we can conclude that clones of the pathogen are thoughtfully selected by host Triticum and Aegilops species, which is consistent with the data of other researchers. Adaptation and specificity to the host plant are the key driving factors of the evolution and divergence of clonally propagating phytopathogens, and leaf rust in particular.

\section{References}

Ablova, I. B., Bespalova, L. A., Kolesnikov, F. A., Nabokov, G. D., Kovtunenko, V.Y., Filobok, V.A., Davoyan, R. O., Khudokormova, Z. N., Mokhova, I. M., Levchenko, Y. G., and Tarkhov, A. S. 2016. Principles and methods of wheat breeding on tolerance to diseases in KRIA named after P. P. Lukiyanenko. Grain Economy of Russia 5:32-36. (In Russian)

Aoun, M., Kolmer, J. A., Breiland, M., Richards, J., Brueggeman, R. S., Szabo, L. J., and Aceved, M. 2020. Genotyping-by-sequencing for the study of genetic diversity in Puccinia triticina. Plant Disease 104:752-760. https://doi. org/10.1094/PDIS-09-19-1890-RE

Barmenkov, A. S. 1938. Geographic distribution leaf rust races (Puccinia triticina Erikss.) in USSA, pp. 180-197 in N. A. Naumov, A. K. Zubarev (eds.) Rusts of cereal crops. Abstracts of first All-Union conference on the protection against rust of cereal crops. Moskow: Sel'hozgiz. (In Russian)

Berlyand-Kozhevnikov, V. M., Dmitriev, A.P., Budashkina, E. B., Shitova, I. T., and Reiter, V. G. 1978. Wheat rust resistance (Genetic diversity of the fungus and host plant populations). Novosibirsk: Nauka. (In Russian)

Bolton, M.D., Kolmer, J. A., and Garvin, D. F. 2008. Wheat leaf rust caused by Puccinia triticina. Molecular Plant Pathology 9(5):563-575. https://doi.org/10.1111/j.13643703.2008.00487.x

Dmitriev, A.P., Mikhaylova, L.A., Shelomova, L. F., and Derevyankin, A. I. 1976. A study of the racial and genotypic composition of the Derbent population of Puccinia recondita Rob. ex Desm. tritici in 1972-1973. Mikologiya $i$ fitopatologiya 10(4):61-64. (In Russian)

Dorofeev, V. F., Udachin, R. A., Semenova, L. V. Novikova, M. V., Gradchaninova, O. D., Shitova, I. P., Merezhko, A. F., and Filatenko, A. A. 1987. Wheat of world. Leningrad: Kolos, 560 p. (In Russian)

Goyeau, H., Berder, J., Czerepak, C., Gautier, A., Lanen, C., and Lannou, C. 2012. Distribution of pathotypes with regard to host cultivars in French wheat leaf rust populations. 
Plant Pathology 61(4):761-772. https://doi.org/10.1094/ PHYTO-96-0264

Gultyaeva, E.I. 2012. Genetic diversity of Russian common wheat varieties for leaf rust resistance. Russian Agricultural Sciences 38:125-128. https://doi.org/10.3103/ S1068367412020115 (In Russian)

Gultyaeva, E. I. 2018. Genetic structure of Puccinia triticina populations in Russia and its variability under the influence of host plant. Doctor of Science Dissertation. Pushkin-St. Petersburg, Russia: All-Russian Institute of Plant Protection, 312 p. (In Russian)

Gultyaeva, E. I., Akhmetova, A. K., Shaidayuk, E. L., and Aristova, M. K. 2016. Population structure of Puccinia triticina Erikss. on bread and durum wheat. Farming and selection of agricultural plants at the present time. Collection of the international scientific and practical conference dedicated to the 60th anniversary of the SPC of grain farming named after A. I. Baraeva. Scientific and Production Center of Grain Economy named after A. I. Baraeva, pp. 309-313. (In Russian)

Gultyaeva, E. I., Baranova, O. A., and Dmitriev, A. P. 2007. Virulence and population structure of Puccinia triticina in Russian Federation in 2007. Plant Protection News 4:333338. (In Russian)

Gultyaeva, E. I., Shreyder, E. R. Shaydayuk, E. L., Atishova, M. N., Madenova, A., Malysheva A., and Galymbek, K. 2020. Genetic variability of perspective breeding material of spring bread wheat for resistance to leaf rust in Russia and Kazakhstan. Bulletin of the National Academy of Sciences of the Republic of Kazakhstan 3:60-68. https:// doi.org/10.32014/2020.2518-1467.70

Lesovoy, M. P. and Suvorova, G.S. 1985. Dynamics of virulence of biotypes of race 77 of the causative agent of wheat leaf rust in the territory of the Ukrainian SSR. Plant Protection 32:5-10. (In Russian)

Liu, M., Rodrigue, N., and Kolmer, J. 2014. Population divergence in the wheat leaf rust fungus Puccinia triticina is correlated with wheat evolution. Heredity 112(4):443453. https://doi.org/10.1038/hdy.2013.123

Mantovani, P., Maccaferri, M., Tuberosa, R., and Kolmer, J. 2010. Virulence phenotypes and molecular genotypes in collections of Puccinia triticina from Italy. Plant Disease 94(4):420-424. https://doi.org/10.1094/PDIS-94-4-0420

Markelova, T. S. 2007. Study of the structure and variability of wheat leaf rust population in the Volga region. AGRO XXI 4-6. (In Russian)

Martinez, F. Sillero, J. C., and Rubiales, D. J. 2005. Pathogenic specialization of Puccinia triticina in Andalusia from 1998 to 2000. Phytopathology 153(6):344-349. https:// doi.org/10.1111/j.1439-0434.2005.00983.x

Meshkova, L. V., Rosseeva, L. P., Sidorov, A. V., Sabaeva, O. V., Zverovskaya, T. S., and Belan I. A. 2019. Hysiological specialization of brown rust pathogen on the wheat in Krasnoyarsk region. Vestnik KrasGAU 6:29-36. (In Russian)

Meshkova, L. V. and Roseeva, L. P. 2016. Physiological specialization of wheat leaf rust pathogen in Omsk region in 2014. Uspekhi sovremennoy nauki 3(10):116-118. (In Russian)

Meshkova, L. V., Roseeva, L.P., Shreider, E. R., and Sidorov, A. V. 2008. Virulence of pathotypes of wheat leaf rust pathogen to ThLrg in Siberia and the Urals. Second All-Russian Conference "Modern problems of plant immunity to harmful organisms", St. Petersburg, pp. 70-73. (In Russian)

Meshkova, L. V., Rosseeva, L. P., Zverovskaya, T. S., Sabaeva, O. B., and Belan I. A. 2018. Virulence of the natural population of the causing agent of wheat leaf rust in the Omsk region. Uspekhi sovremennogo yestestvoznaniya 11(2):279-283. (In Russian)
Mikhailova, L. A. 2006. Genetics of the interrelation between leaf rust pathogen and wheat. St. Petersburg: VIZR. 80 p. (In Russian)

Mikhailova, L. A. and Metreveli, T. G. 1986. Structure of Puccinia triticina Rob. ex Desm. f sp. tritici Erikss. on different kinds of wheat. Mikologiya i fitopatologiya 20(2):138-142. (In Russian)

Morgounov, A., Ablova, L., Babayants, O., Babayants, L., Bespalova, L., Khudokormova, Zh., Litvinenko, N., Shamanin, V., and Syukov, V. 2011. Genetic protection of wheat rusts and development of resistant varieties in Russia and Ukraine. Euphytica 179(2):297-311. https://doi. org/10.1007/s10681-010-0326-5

Novozhilov, K. V., Levitin, M. M., Mikhailova, L. A., and Gultyaeva E. I. 1998. Principles of using parent material in breeding wheat for leaf rust resistance. Vestnik of the Russian agricultural sciences 1:61-64. (In Russian)

Odintsova, I. G. and Khristov, Yu. A. 1981. Migration of aerogenic infection $P$. recondita and $P$. graminis on the territory of the USSR. Abstracts of the 7th All-Union Committee on Immunity of Agricultural Plants to Diseases and Pests (Omsk, August 4-7), pp. 39-40. (In Russian)

Ordoñez, M. E. and Kolmer, J. A. 2007. Virulence phenotypes of a worldwide collection of Puccinia triticina from durum wheat. Phytopathology 97(3):344-351. https://doi. org/10.1094/PHYTO-97-3-0344

Sanin, S. S. 1975. Development of wheat leaf rust in the North Caucasus in 1973: causes of epiphytotics. Mikologiya i fitopatologiya 9(1):37-42. (In Russian)

Shaydayuk, E. L. Population structure of Puccinia triticina on durum wheat in Russia. Candidate of Science Dissertation. Pushkin-St. Petersburg, Russia: All-Russian Institute of Plant Protection. 114 p. (In Russian)

Shaydayuk, E. L., Gultyaeva, E.I., Malchikov, P. N., Rozova, M. A., and Korobeinikov, N.I. 2019. Comparative analysis of Puccinia triticina populations on common and durum wheat. Mikologiya i fitopatologiya 53(3):170-176. https://doi.org/10.1134/S0026364819030115

Shopina, V.V. 1969. Changes in racial composition of leaf rust on wheat in country. Proceedings of the V All-Union Conference on Plant Immunity 2. Grain crops, Kiev 3, pp. 80-89. (In Russian)

Sibikeev, S. N. and Krupnov, V. A. 2007. Evolution of leaf rust and protection from it in the Volga region. Vestnik Saratovskogo gosuniversiteta im Vavilova 92-94. (In Russian)

Sibikeev, S. N., Markelova, T.S., Druzhin, A. E., Vedeneeva, M. L., and Singkh, D. 2011. Evaluation of a set of introgressive spring bread wheat lines developed for resistance to stem rust race Ug99 + Sr24 (TTKST) at the Southeast Agricultural Research Institute. Russian Agricultural Sciences 37(2):95-97. https://doi.org/10.3103/ S1068367411020236 (In Russian)

Sibikeev, S. N., Voronina, S. A., and Krupnov, V. A. 1995. Genetic control for resistance to leaf rust in wheat-Agropyron lines: Agro 139 and Agro 58. Theoretical and Applied Genetics 90(5):618-620. https://doi.org/10.1007/ BF00222124

Singh, R. P., Huerta-Espino, J., Pfeiffer, W., and Figueroa-Lopez, P. 2004. Occurrence and impact of a new leaf rust race on durum wheat in Northwestern Mexico from 2001 to 2003. Plant Disease 88:703-708. https://doi. org/10.1094/PDIS.2004.88.7.703

Sorokina, G. K. and Solomatin, D. A. 1975. Dynamics of the racial composition of the causative agent of wheat leaf rust and immunological characteristics of regional varieties. Abstracts of the 6th All-Union Committee on Immunity of Agricultural Plants to Diseases and Pests (Odessa, November 11-14). Moscow, pp. 158-159. (In Russian) 
Tsitsin, N. V. 1981. Theory and practice of alien hybridization. Moscow, 160 p. (In Russian)

Tyunin, V. A., Shreider, E. R., Gultyaeva, E. I., and Shaydayuk, E. L. 2017. Characteristics of virulence of Puccinia triticina populations and the potential of the Lr24, Lr25, LrSp genes for spring common wheat breeding in the Southern Ural. Vavilov Journal of Genetics and Breeding 21(5):523-529. https://doi.org/10.18699/VJ17.269 (In Russian)

Vavilov, N. I. 1938. Breeding resistant varieties as the main method of rust control, pp. 3-20 in N.A. Naumov, A. K. Zubarev (eds.) Rusts of cereal crops. Abstracts of first All-Union conference on the protection against rust of cereal crops. Moskow: Sel'hozgiz. (In Russian)
Volkova, G. V., Kudinova, O. A., and Vaganova, O. F. 2019. Diversity of virulence phenotypes of Puccinia triticina in different agroclimatic zones of the North Caucasus. Russian Agricultural Sciences 6:23-26. https://doi.org/10.31857/ S2500-26272019623-26 (In Russian)

Voronkova, A. 1980. Genetics and immunological basis of wheat breeding for rust resistance. Moscow: Kolos, 191 p. (In Russian)

Zhemchuzhina, A.l., Kurkova, N. N., and Kovalenko, E.D. 2008. Virulence of wheat leaf rust pathogen in Russia in 2000-2005. 50 years guarding the food security of the country. Jubilee collection of works. Bolshie Vyazemy, pp. 325-330. (In Russian) 